\title{
Phytochemical Study of Eight Medicinal Plants of the Lamiaceae Family Traditionally Used as Tea in the Sharri Mountains Region of the Balkans
}

\author{
Avni Hajdari, ${ }^{1}$ Behxhet Mustafa, ${ }^{1}$ Lirie Hyseni, ${ }^{1}$ Ani Bajrami, ${ }^{2}$ Genista Mustafa, ${ }^{3}$ \\ Cassandra L. Quave, ${ }^{4}$ and Dashnor Nebija $\oplus^{5}$ \\ ${ }^{1}$ Department of Biology, Faculty of Mathematical and Natural Science, University of Prishtina "Hasan Prishtina", \\ Mother Theresa St., 10000 Prishtina, Kosovo \\ ${ }^{2}$ Faculty of Natural Sciences, University of Tiran, Boulevard "Dëshmorët e Kombit", Square "Mother Teresa" No. 183, \\ 1001 Tirana, Albania \\ ${ }^{3}$ Faculty of Medicine, University of Prishtina "Hasan Prishtina", St. Bulevardi I Dëshmorëve, 10000 Prishtina, Kosovo \\ ${ }^{4}$ Center for the Study of Human Health, Emory University, 1557 Dickey Drive, Room 306, Atlanta, GA 30322, USA \\ ${ }^{5}$ Department of Pharmaceutical Chemistry, Faculty of Medicine, University of Prishtina "Hasan Prishtina", \\ Bulevardi I Dëshmorëve, p.n. 10000 Prishtina, Kosovo
}

Correspondence should be addressed to Dashnor Nebija; dashnor.nebija@uni-pr.edu

Received 5 November 2019; Accepted 28 January 2020; Published 19 February 2020

Academic Editor: Qiquan Wang

Copyright (C) 2020 Avni Hajdari et al. This is an open access article distributed under the Creative Commons Attribution License, which permits unrestricted use, distribution, and reproduction in any medium, provided the original work is properly cited.

In the present study, eight plant species belonging to Lamiaceae family were identified as ingredients for herbal teas in the region of Sharri Mountains: Thymus serpyllum, Rosmarinus officinalis, Melissa officinalis, Origanum vulgare, Mentha longifolia, Ocimum basilicum, Teucrium chamaedrys, and Sideritis scardica, respectively. Chemical composition of essential oils obtained from these species was analyzed using GC-MS and GC-FID with the aim of examining their volatile compound profiles, responsible for their respective flavors and fragrance. Principal Component Analysis (PCA) was performed with the aim of grouping plant species under study on the basis of their chemical composition. Experimental data revealed the typical volatile constituent pattern for the Lamiaceae family. Monoterpenes and sesquiterpenes, responsible for flavor and medicinal use of these plants, were the most abundant groups of the volatile constituents. PCA data analysis resulted in the grouping of these analyzed species in four principal clusters.

\section{Introduction}

The Sharri Mountains region (in Albanian known as Malet e Sharrit; in Macedonian and Serbian as Šar-Planina) is one of the biggest mountain massifs in Balkans $\left(1,600 \mathrm{~km}^{2}\right)$ and is situated in the Republic of North Macedonia (in a total area of $826.8 \mathrm{~km}^{2}$ or $51.44 \%$ ) and Republic of Kosovo (in a total area of $780.4 \mathrm{~km}^{2}$ or 48.56\%) [1]. This region serves as a tremendous reservoir of Traditional Environmental Knowledge (TEK) related to wild plants because of its complex biocultural diversity (hotspot of biodiversity and home to a variety of different ethnic and religious groups), the socioeconomic environment, and the long held traditions in the collection of wild plants by local inhabitants.

To date, there are roughly 1,500 vascular plant species known to grow in the Sharri Mountains [2, 3]. In addition to local species richness, the region is also rich in cultural, linguistic, and religious diversity. Various ethnic groups, including Albanians, Bosniaks, and Gorani (Muslims) and Serbs (Christian Orthodox) live on the Kosovo side of the Sharri, while the Macedonian side is inhabited by Albanians and Gorani (Muslims) and Macedonians (Christian Orthodox). These ethnic groups have lived in close contact over a span of many centuries in villages that are isolated from urban areas. 
Local communities have benefited from the rich biodiversity of the region over centuries and for a variety of different purposes, including as ingredients in the creation of medicine, food, beverages, and snacks and as recreational teas. [2, 4-12]. Traditional uses of plants as recreational tea in Sharri have been reported in an ethnobotanical study, which covers other European countries as well [10]. In this article, we use the term "tea" to refer to herbal beverages prepared as infusions and that are consumed as food, excluding those teas prepared and consumed only for specific medicinal purposes, as well as black tea (Camellia sinensis (L.) Kuntze).

A review of the current literature revealed that study of the chemical composition of species found in Sharri was restricted primarily to those used mainly for pharmaceutical preparations [13-16]. Only a few reports on the chemical composition of species used for tea in the Sharri region and collected from Sharri have been published thus far. These include reports on the chemical composition of Origanum vulgare L. and Malus sylvestris Mill. collected from the Kosovo side of Sharri $[17,18]$ and another on the chemical composition of the essential oils of Sideritis scardica Griseb. from the North Macedonia side of Sharri [18].

Nevertheless, there is a growing interest in research on the chemical composition of specific herbal teas produced commercially in different regions of the world [19]. Hence, the aim of this study was twofold: first, to identify plant species which are traditionally used for herbal tea preparation in Kosovo through review of the ethnobotanical literature; second, to analyze their chemical composition and identify volatile compounds thought to be responsible for their flavor, fragrance, and health benefits.

\section{Materials and Methods}

2.1. Plant Material. Plants species were chosen based on the review of numerous ethnobotanical studies and published ethnographies, as well as unpublished fieldwork results originating from Sharri (Kosovo and North Macedonia). Species used in water infusions as aromatic and refreshing hot beverages (recreational tea) consumed in food and not for specific medicinal purposes were selected.

Plant material (specific plant tissues used to prepare tea) was either collected in the Sharri region from wild populations or purchased from the local markets, provided by local residents in Prizren (Kosovo) and Tetovo (Macedonia) that wildcrafted or cultivated the materials in Sharri for personal or family use. Plant material was collected from May to September and stored in a dry place protected from light until analyzed.

Taxonomic identification followed relevant standard botanical literature of the area [20]. Botanical nomenclature and family assignments followed the Plant List database [21], and voucher specimens were deposited at the University of Prishtina Herbarium.

2.2. Plant Material Extraction. Plant material was air-dried in the shade at room temperature, and volatile compounds were obtained by hydrodistillation, standard extraction method of volatile compounds, using a Clevenger apparatus for 2 hours. The extracts were stored at $-18^{\circ} \mathrm{C}$ in a freezer until further analysis.

2.3. GC-MS Analysis. GC-MS analysis using an Agilent 7890A GC system coupled to a 5975C MSD (Agilent Technologies) was used for the separation and identification of essential oils constituents. The ionization energy was $70 \mathrm{eV}$. The separation was conducted in HP-5MS column $(30 \mathrm{~m} \times 0.25 \mathrm{~mm}$ i.d., film thickness $0.25 \mathrm{~mm})$. The carrier gas used was $\mathrm{He}$, with an initial flow rate of $0.6 \mathrm{~mL} / \mathrm{min}$ and subsequently at a constant pressure of $50 \mathrm{psi}$. The carrier gas used was He with a constant flow rate $1.0 \mathrm{~mL} / \mathrm{min}$, injection temperature $280^{\circ} \mathrm{C}$, injection volume $1.0 \mu \mathrm{L}$, and a split ratio of 25:1. The initial GC oven temperature was $60^{\circ} \mathrm{C}(5 \mathrm{~min})$ and was increased from $60^{\circ} \mathrm{C}$ to $200^{\circ} \mathrm{C}$ at a rate of $5^{\circ} \mathrm{C} / \mathrm{min}$.

2.4. GC-FID Analysis. GC-FID analyses were performed using an Agilent 7890A GC system equipped with an FID detector (Agilent Technologies). The separation was conducted on a HP-5MS column $(30 \mathrm{~m} \times 0.1 \mathrm{~mm}$, with $0.17 \mu \mathrm{m}$ film thickness). The carrier gas used was $\mathrm{He}$, with an initial flow rate of $0.6 \mathrm{~mL} / \mathrm{min}$ and subsequently at a constant pressure of $50^{\circ} \mathrm{psi}$. The GC oven temperature increased from $60^{\circ} \mathrm{C}$ to $160^{\circ} \mathrm{C}$ at a rate of $10^{\circ} \mathrm{C} / \mathrm{min}$ and subsequently to $280^{\circ} \mathrm{C}$ at a rate of $20^{\circ} \mathrm{C} / \mathrm{min}$., and the FID operated at $250^{\circ} \mathrm{C}$ with an air flow of $350 \mathrm{~mL} / \mathrm{min}$ and a hydrogen flow of $35 \mathrm{~mL} / \mathrm{min}$. The injection volume was $1.0 \mathrm{~mL}$.

2.5. Identification of Essential Oil Components. The identification of each of the components of the essential oil was performed by comparing their Kovats retention indices with those reported in the literature [22]. The Kovats index was calculated based on a linear interpolation of the retention times of a homologous series of $n$-alkanes (C9-C28) under the same operating conditions. The components were also identified by comparing the mass spectra of each constituent with those stored in the NIST 08 and WILEY MS $9^{\text {th }}$ databases and with mass spectra from the literature [22]. The percentage composition of the oils was computed using the normalization method from the GC peak areas, calculated as the mean of three samples, without correction factors.

2.6. Statistical Analysis. Principal Component Analysis (PCA) was used for multivariate association between volatile constituents and plant species in the study. Chemical compounds present in percentages higher than 3\% were selected for statistical analysis. The XLSTAT program (version 2014.2.03) was used for the PCA and HCA.

\section{Results and Discussion}

In total, eight plant species belonging to the Lamiaceae family were identified as being used for making recreational herbal teas (Tables 1 and 2). Members of the Lamiaceae (and Rosaceae) family are well-known as local herbal teas in eastern and central Europe [10]. 
3.1. Statistical Analysis. Principal Component Analysis (PCA) has been used with the aim of grouping plant species of the Lamiaceae family, which have been used traditionally as teas on the basis of their chemical composition.

Principal Component Analysis demonstrated that eight plant species examined in this study have been grouped in four principal groups. Thymus serpyllum in the first group, Rosmarinus officinalis in the second group, and Melissa officinalis in the third group, whereas the fourth group included Origanum vulgare, Mentha longifolia, Ocimum basilicum, Teucrium chamaedrys, and Sideritis scardica, with greater similarities in relation to their chemical composition (Figure 1).

3.2. Chemical Composition of Volatile Compounds of Lamiaceae Species. Volatile compounds of eight species of the Lamiaceae family were analyzed in total, and results have been presented in Table 1.

3.2.1. Melissa officinalis L., Lamiaceae. Twenty-three compounds were identified using GC-MS analysis of essential oils obtained from the distillation of aerial parts of the lemon balm, Melissa officinalis (Table 1). These compounds predominantly belonged to the class of oxygenated sesquiterpenes (28.56\%) and oxygenated monoterpenes (20.38\%), while percentage of sesquiterpenes was $9.18 \%$ followed by fatty acids and their derivatives, hydrocarbons, and monoterpenes with their respective percentages of $5.59 \%$, $4.77 \%$, and $3.78 \%$ (Table 1). The most abundant compounds were geranial $(20.38 \%)$, spathulenol $(18.61 \%)$, E-caryophyllene (7.32\%), dodecanoic acid (5.59\%), elemol (4.21\%), limonene (2.61\%), $n$-pentacosane $(2.08 \%)$, and caryophyllene oxide (1.99\%) (Table 1). In the lemon balm samples growing in Turkey, the monoterpene, D-limonene was the most prominent constituent $(26.00 \%)$, citral and neral were more prominent oxygenated monoterpenes (14.93\% and $13.6 \%$, respectively), and caryophyllene oxide was the most abundant oxygenated sesquiterpene (11.45\%) [23]. In samples from Greece, monoterpenes ( $\beta$-pinene and sabinene), sesquiterpene (E)-caryophyllene, and oxygenated sesquiterpene (caryophyllene oxide) were major constituents, and citral and citronellal were absent [24]. In Serbian commercial samples of the essential oil of lemon balm, the most prominent compounds identified in the essential oil were oxygenated monoterpenes, citronellal, geranial, $\alpha$-terpineol, $\alpha$-terpinyl acetate, neral, and the monoterpene, limonene. [25].

3.2.2. Mentha longifolia L., Lamiaceae. In essential oils obtained from aerial parts of wild mint, Mentha longifolia, twenty-nine compounds were identified. The dominant components are oxygenated monoterpenes (89.46\%) and monoterpenes $(2.85 \%)$, followed by sesquiterpenes $(5.43 \%)$ and oxygenated sesquiterpenes $(2.05 \%)$. The most abundant compound is the oxygenated monoterpene, menthone (73.77\%). In lesser amounts are present iso-menthyl acetate (4.1\%), 1.8-cineole (3.69\%), and isomenthol (3.35\%)
(Table 2). Peak areas of sesquiterpenes, $\beta$-ylangene and $\gamma$-muurolene, are $2.77 \%$ and $2.23 \%$, respectively. In a report by Stanisavljević et al. [26], the main components of essential oils obtained from this species, dried by three different techniques, were piperitone, carvone, menthone, limonene, trans-caryophyllene, $\gamma$-muurolene, 1,8 -cineole, and cisdihydrocarvone. The principal constituents in the mint oil from Serbia were trans-dihydrocarvone (23.64\%), piperitone (17.33\%), and cis-dihydrocarvone (15.68\%) [27], whereas in samples from Bosnia and Herzegovina, the main constituents of the essential oil of M. longifolia leaves were oxygenated monoterpenes, piperitone oxide $(63.58 \%)$ and 1.8 cineole (12.03\%), followed by the oxygenated sesquiterpene, caryophyllene oxide (4.33\%), and sesquiterpenes, transcaryophyllene (2.98\%) and cis-caryophyllene (0.82\%) [28]. Similarly, in samples from Croatia, the dominant constituents were oxygenated monoterpenes (69\% of the oil), followed by monoterpenes and sesquiterpenes (31\% of the oil) [29].

3.2.3. Ocimum basilicum L., Lamiaceae. In essential oils obtained from the aerial parts of basil, Ocimum basilicum, fifty-six compounds were identified. Phenylpropanoids were the principal constituents, constituting $62.8 \%$, followed by sesquiterpenes and their oxygenated derivatives (14.14 and $10.19 \%$ respectively). Oxygenated monoterpenes and monoterpene hydrocarbons were present in smaller amounts (11.55\% and $1.3 \%$, respectively). The phenylpropanoid derivatives, methyl chavicol (estragole) (45.82\%) and methyl eugenol (12.1\%), were the most prominent compounds. Sesquiterpenes and oxygenated sesquiterpenes (E-caryophyllene, 4.08\%; elemol, 2.62\%; spathulenol, 2.54\%; bicyclogermacrene, 2.33\%; $\alpha$-trans-bergamotene, $1.97 \%$; germacrene $D, 1.81 \%$ ) constituted the second abundant class of compounds (Table 1). The respective percentages of oxygenated monoterpenes, linalool and 1,8-cineole, were $4.77 \%$ and $3.89 \%$, and the aromatic ketone, benzophenone, was present in the percentage of $2.7 \%$. Therefore, experimental data of our study revealed that $O$. basilicum samples growing in Kosovo belonged to the methyl chavicol chemotype. The phenylpropanoid compound, methyl chavicol (estragole), was the main component from basil samples from Turkey (78.02\%), followed by methyl eugenol (78.02\%), $\alpha$-cubebene (6.17\%), nerol $(0.83 \%)$, and $e$ muurolene $(0.74 \%)$ [30]. In O. basilicum samples from Croatia, the major monoterpene alcohol, linalool (28.6\%), was followed by estragole (21.7\%). Other important compounds were (E)-methyl cinnamate (14.3\%), alpha-cadinol (7.1\%), eugenol (5.9\%), 1,8-cineole (4.0\%), methyl eugenol (3.1\%), and $\alpha$-bergamotene (2.2\%) [31].

3.2.4. Origanum vulgare L., Lamiaceae. Thirty-nine compounds were identified using GC-MS analysis of essential oils obtained from the distillation of aerial parts of the oregano, Origanum vulgare L. These compounds predominantly belonged to the class of sesquiterpenes and their oxygenated derivatives ( $36.92 \%$ and $10.57 \%$, respectively) and monoterpenes and their oxygenated derivatives $(23.32 \%$ 
TABLE 1: Phytochemical analysis of essential oils obtained from the extracts of plants used as teas, belonging to the Lamiaceae family.

\begin{tabular}{|c|c|c|c|c|c|c|c|c|c|}
\hline $\begin{array}{l}\text { Compound name and } \\
\text { class }\end{array}$ & $\begin{array}{c}\text { Kovats } \\
\text { index }\end{array}$ & $\begin{array}{l}\text { Ocimum } \\
\text { basilicum }\end{array}$ & $\begin{array}{l}\text { Mentha } \\
\text { longifolia }\end{array}$ & $\begin{array}{l}\text { Teucrium } \\
\text { chamaedrys }\end{array}$ & $\begin{array}{l}\text { Sideritis } \\
\text { scardica }\end{array}$ & $\begin{array}{l}\text { Thymus } \\
\text { serpyllum }\end{array}$ & $\begin{array}{l}\text { Rosmarinus } \\
\text { officinalis }\end{array}$ & $\begin{array}{l}\text { Melissa } \\
\text { officinalis }\end{array}$ & $\begin{array}{l}\text { Origanum } \\
\text { vulgare }\end{array}$ \\
\hline$\alpha$-Pinene & 939 & 0.25 & 0.46 & 1.34 & 1.33 & - & 10.83 & - & 0.49 \\
\hline Camphene & 954 & - & - & - & - & - & 3.28 & - & - \\
\hline Sabinene & 975 & - & 0.36 & - & - & - & - & - & 11.16 \\
\hline 1-Octen-3-ol & 979 & - & - & 2.92 & - & - & - & - & - \\
\hline$\beta$-Pinene & 979 & 0.16 & 0.64 & - & 2.35 & - & 0.57 & - & - \\
\hline Myrcene & 990 & 0.39 & 0.44 & - & - & 0.51 & 2.54 & - & 0.33 \\
\hline$o$-Cymene & 1026 & - & - & - & - & - & - & 0.61 & 1.02 \\
\hline Limonene & 1029 & - & 0.62 & 0.70 & 0.65 & 3.10 & - & 2.61 & - \\
\hline$p$-Cymene & 1031 & - & - & - & - & - & 2.58 & - & - \\
\hline 1.8-cineole & 1031 & 3.89 & 3.69 & - & - & - & 19.32 & - & 1.44 \\
\hline $\mathrm{Z}$ - $\beta$-Ocimene & 1037 & - & 0.17 & - & - & 1.25 & - & - & 2.18 \\
\hline E- $\beta$-Ocimene & 1050 & 0.13 & 0.10 & - & - & 2.20 & - & - & 2.72 \\
\hline$\gamma$-Terpinene & 1059 & 0.23 & - & - & - & - & 0.52 & - & 3.23 \\
\hline Linalool & 1096 & 4.77 & - & 0.34 & - & 16.90 & 1.96 & - & - \\
\hline$\alpha$-Terpinene & 1017 & - & - & - & - & 7.11 & - & - & - \\
\hline Camphor & 1146 & - & 1.37 & - & - & - & 13.71 & - & - \\
\hline Menthone & 1152 & - & 73.77 & - & - & - & - & - & - \\
\hline Borneol & 1169 & 0.20 & - & - & - & - & 4.41 & - & 0.49 \\
\hline Terpinen-4-ol & 1177 & - & - & - & - & - & 1.02 & - & 1.45 \\
\hline Isomenthol & 1182 & - & 3.30 & - & - & - & - & - & - \\
\hline$\alpha$-Terpineol & 1188 & - & 0.54 & 0.15 & - & - & 2.67 & - & 0.83 \\
\hline Dihydrocarveol & 1193 & - & - & - & - & 1.70 & - & - & - \\
\hline Verbenone & 1205 & - & - & - & - & - & 3.00 & - & - \\
\hline Linalool acetate & 1254 & - & - & - & - & 22.35 & - & - & - \\
\hline Geranial & 1267 & - & - & 0.80 & - & - & - & 20.38 & - \\
\hline Isobornyl acetate & 1285 & 0.17 & - & - & 0.16 & - & 3.74 & - & - \\
\hline Thymol & 1290 & 0.40 & 0.50 & - & 0.20 & - & 3.10 & - & 3.17 \\
\hline Carvacrol & 1298 & 0.12 & - & - & - & - & 0.54 & - & 10.23 \\
\hline Menthyl acetate & 1295 & - & 1.16 & - & - & - & - & - & - \\
\hline iso-Menthyl acetate & 1304 & - & 4.10 & - & - & - & - & - & - \\
\hline$\alpha$-Copaene & 1376 & 0.14 & - & 0.66 & 0.65 & - & - & - & - \\
\hline E-methyl cinnamate & 1378 & 1.05 & - & - & - & - & - & - & - \\
\hline Geranyl acetate & 1381 & - & - & - & - & 2.19 & - & - & - \\
\hline$\beta$-Bourbonene & 1388 & - & - & 2.47 & 0.28 & - & - & - & 0.82 \\
\hline iso-Longifolene & 1390 & - & - & 2.20 & - & - & - & - & - \\
\hline$\beta$-Elemene & 1390 & 0.57 & - & - & 1.02 & - & - & - & 0.29 \\
\hline Methyl eugenol & 1403 & 12.10 & - & - & - & - & - & - & - \\
\hline E-Caryophyllene & 1419 & 4.08 & - & 3.96 & 3.90 & 8.43 & 11.58 & 7.32 & 10.49 \\
\hline B-Ylangene & 1420 & - & 2.77 & - & - & - & - & - & - \\
\hline$\alpha$-trans-Bergamotene & 1434 & 1.97 & - & - & - & - & - & - & - \\
\hline$\beta$-Copaene & 1432 & - & - & 1.04 & - & - & - & - & 0.23 \\
\hline a-Humulene & 1454 & 0.14 & 0.13 & 0.87 & - & 8.87 & 0.39 & 0.22 & 1.47 \\
\hline E- $\beta$-Farnesene & 1456 & - & - & - & 1.05 & - & - & - & - \\
\hline$\gamma$-Muurolene & 1480 & - & 2.23 & - & - & 0.87 & - & - & - \\
\hline Germacrene D & 1481 & 1.81 & - & 24.10 & 2.54 & - & 1.35 & 0.29 & 14.20 \\
\hline cis-B-guaiene & 1493 & - & - & 1.07 & - & - & - & - & - \\
\hline$\beta$-Macrocarpene & 1499 & - & - & 1.81 & - & - & - & - & - \\
\hline Bicyclogermacrene & 1500 & 2.33 & 0.18 & - & - & 1.08 & - & 0.30 & 2.88 \\
\hline$\beta$-Bisabolene & 1505 & - & - & 0.95 & - & - & 0.45 & - & 2.48 \\
\hline Germacrene a & 1509 & - & - & - & - & 3.53 & - & - & - \\
\hline Cubebol & 1515 & - & - & - & - & - & - & 1.04 & - \\
\hline$\delta$-Cadinene & 1523 & 0.45 & 0.12 & 6.97 & - & - & - & 1.05 & 2.87 \\
\hline Zonarene & 1529 & - & - & - & 1.30 & - & 0.38 & - & - \\
\hline$\Gamma$-Cuprenene & 1533 & 0.47 & - & 1.62 & - & - & - & - & - \\
\hline Elemol & 1549 & 2.62 & - & - & - & - & - & 4.21 & 1.39 \\
\hline Dodecanoic acid & 1566 & - & - & 1.46 & - & - & - & 5.59 & - \\
\hline Spathulenol & 1578 & 2.54 & 0.32 & 0.57 & 0.34 & - & - & 18.61 & 0.88 \\
\hline Caryophyllene oxide & 1583 & 1.41 & 0.19 & 1.21 & 2.09 & 0.53 & 1.17 & 1.99 & 2.18 \\
\hline Benzophenone & 1627 & 2.70 & - & - & - & - & - & - & - \\
\hline
\end{tabular}


TABle 1: Continued.

\begin{tabular}{|c|c|c|c|c|c|c|c|c|c|}
\hline $\begin{array}{l}\text { Compound name and } \\
\text { class }\end{array}$ & $\begin{array}{c}\text { Kovats } \\
\text { index }\end{array}$ & $\begin{array}{l}\text { Ocimum } \\
\text { basilicum }\end{array}$ & $\begin{array}{l}\text { Mentha } \\
\text { longifolia }\end{array}$ & $\begin{array}{c}\text { Teucrium } \\
\text { chamaedrys }\end{array}$ & $\begin{array}{l}\text { Sideritis } \\
\text { scardica }\end{array}$ & $\begin{array}{l}\text { Thymus } \\
\text { serpyllum }\end{array}$ & $\begin{array}{l}\text { Rosmarinus } \\
\text { officinalis }\end{array}$ & $\begin{array}{l}\text { Melissa } \\
\text { officinalis }\end{array}$ & $\begin{array}{l}\text { Origanum } \\
\text { vulgare }\end{array}$ \\
\hline $\begin{array}{l}\text { Caryophylla-4 (12), } 8 \\
\text { (13)-diene- } 5 \beta \text {-ol }\end{array}$ & 1640 & - & - & - & 0.25 & - & 1.87 & - & - \\
\hline Epi-a-muurolol & 1642 & - & - & 1.00 & - & - & - & - & 1.63 \\
\hline Cubenol & 1646 & 0.15 & - & 0.64 & - & 0.66 & - & - & 3.46 \\
\hline$\alpha$-Cadinol & 1654 & 0.33 & 1.10 & 0.70 & 1.45 & 0.54 & - & - & - \\
\hline 7-Epi- $\alpha$-eudesmol & 1663 & - & - & - & - & - & 2.29 & - & - \\
\hline Khusinol & 1676 & - & - & - & - & - & 2.37 & - & - \\
\hline Epi- $\alpha$-bisabolol & 1684 & 0.22 & - & 1.12 & - & - & 1.88 & 0.63 & - \\
\hline$\alpha$-Costol & 1774 & - & - & - & 1.24 & - & - & - & - \\
\hline Cyclopentadecanolide & 1833 & - & - & - & 1.12 & - & - & - & - \\
\hline E,E-farnesyl acetate & 1843 & - & - & 3.27 & - & - & - & - & - \\
\hline Phenyl ethyl octanoate. & 1847 & - & - & 0.84 & 1.17 & - & - & - & - \\
\hline Isophyllocladene & 1968 & - & - & - & 2.33 & - & - & - & - \\
\hline Hexadecanoic acid & 1995 & - & - & 12.09 & 12.68 & - & - & - & - \\
\hline Eicosane & 2000 & - & - & - & 10.89 & - & - & - & - \\
\hline Sclareolide & 2066 & - & - & - & 5.52 & - & - & - & - \\
\hline N-Octadecanol & 2077 & - & - & - & 1.08 & - & - & - & - \\
\hline Pseudo-phytol & 2018 & - & - & 3.25 & - & - & - & - & - \\
\hline Linoleic acid & 2133 & - & - & 6.03 & 3.99 & - & - & - & - \\
\hline Oleic acid & 2142 & - & - & - & 1.83 & - & - & - & - \\
\hline$n$-Docosane & 2200 & - & - & 2.94 & 0.75 & - & - & - & - \\
\hline$n$-Tricosane & 2300 & - & - & 1.54 & 2.31 & - & - & - & - \\
\hline Isopimarol & 2310 & - & - & - & 1.54 & 1.90 & - & 0.63 & - \\
\hline$n$-Pentacosan & 2500 & - & - & - & 0.34 & 4.30 & - & 2.08 & - \\
\hline Hexacosane & 2600 & - & - & - & 4.54 & 1.30 & - & 0.69 & - \\
\hline Heptacosane & 2700 & - & - & - & - & 4.16 & - & - & - \\
\hline Octacosane & 2800 & - & - & - & 1.18 & 2.94 & - & 1.74 & - \\
\hline Total & & 99.98 & 99.99 & 99.01 & 94.3 & 99.99 & $10-$ & 72.89 & 89.07 \\
\hline Monoterpenes & & 1.30 & 2.85 & 2.04 & 4.33 & 14.17 & 22.48 & 3.78 & 23.32 \\
\hline $\begin{array}{l}\text { Oxygenated } \\
\text { monoterpenes }\end{array}$ & & 11.55 & 89.46 & 2.71 & 1.16 & 44.81 & 53.47 & 20.38 & 18.26 \\
\hline Sesquiterpenes & & 14.14 & 5.43 & 49.30 & 12.92 & 22.78 & 14.15 & 9.18 & 36.92 \\
\hline $\begin{array}{l}\text { Oxygenated } \\
\text { sesquiterpenes }\end{array}$ & & 10.19 & 2.05 & 11.03 & 14.74 & 2.38 & 9.58 & 28.56 & 10.57 \\
\hline Diterpenes & & - & - & - & 4.31 & - & - & - & - \\
\hline Oxygenated diterpenes & & - & - & 3.97 & 11.50 & 1.90 & - & 0.63 & - \\
\hline $\begin{array}{l}\text { Fatty acids and } \\
\text { derivatives }\end{array}$ & & - & 0.20 & 23.90 & 22.25 & 0.42 & 0.32 & 5.59 & - \\
\hline Hydrocbons & & - & - & 4.92 & 20.72 & 13.53 & - & 4.77 & - \\
\hline $\begin{array}{l}\text { Phenylpropanoids and } \\
\text { other compounds }\end{array}$ & & 62.8 & - & 0.75 & 0.50 & - & - & - & - \\
\hline Unknown & & - & - & 0.39 & 1,87 & - & - & - & - \\
\hline
\end{tabular}

and $18.26 \%$, respectively). The most prominent compounds were germacrene $D(14.2 \%)$, sabinene $(11.16 \%)$, E-caryophyllene (14.9\%), carvacrol (10.23\%), cubenol $(3.46 \%)$, $\gamma$-terpinene $(3.23 \%)$, thymol $(3.17 \%)$, bicyclogermacrene $(2.88 \%), \quad d$-cadinene $(2.87 \%), \quad$ E- $\beta$-ocimene $(2.72 \%)$, $\beta$-bisabolene $(2.48 \%), \mathrm{Z}$ - $\beta$-ocimene $(2.18 \%)$, and caryophyllene oxide $(2.18 \%)$ (Table 1$)$.

In samples originating from Kosovo, essential oils were characterized by the presence of the following constituents: sabinene (1.81-12.34\%), caryophyllene oxide (0.18-38.05\%), 1,8 cineole $(1.31-13.54 \%), \beta$-caryophyllene with its isomers (E-) $(0.48-14.0 \%)$ and (Z-) $(4.63-12.33 \%)$, para-cymene (1.27-19.62\%), $\alpha$-terpineol (1.05-19.23\%) and germacrene $D$ $(0.35-16.09 \%), \beta$-ocimene with its isomers $(\mathrm{Z}-)$ - $\beta$-ocimene $(0.76-7.6 \%)$ and $(E)-\beta$-ocimene $(0.47-8.06 \%)$, spathulenol
(0.41-5.39\%), and linalool (0.99-4.37\%). Regarding the composition of volatile compounds, the high percentages of oxygenated monoterpenes detected in our study (i.e., thymol and carvacrol) have also been reported in oregano sourced from Croatia, Italy, and Serbia [32-35].

3.2.5. Rosmarinus officinalis L., Lamiaceae. Thirty compounds were identified in the essential oil obtained by hydrodistillation of the aerial parts of rosemary, Rosmarinus officinalis. The principal classes of compounds were oxygenated monoterpenes (53.47\%) and monoterpenes (22.48\%), followed by sesquiterpenes (14.15\%) and oxygenated sesquiterpenes $(9.58 \%)$. The most abundant oxygenated monoterpenes were 1.8-cineole (19.32\%), camphor 
TABLE 2: List of the selected plant species used for tea preparation.

\begin{tabular}{lccc}
\hline Plant species & Plant organs used & Plant origin & Frequency of use \\
\hline Origanum vulgare L. & Aerial parts of plant & Wild & Still being used \\
Thymus serpyllum L. & Aerial parts of plant & Wild & Still being used \\
Mentha longifolia (L.) L. & Aerial parts of plant & Wild & Occasionally used \\
Melissa officinalis L. & Aerial parts of plant & Wild & Occasionally used \\
Ocimum basilicum L. & Aerial parts of plant & Wild & Occasionally used \\
Teucrium chamaedrys L. & Aerial parts of plant & Wild & Rarely used \\
Sideritis scardica Griseb. & Aerial parts of plant & Cultivated & Still being used \\
Rosmarinus officinalis L. & Aerial parts of plant & Rarely used \\
\hline
\end{tabular}

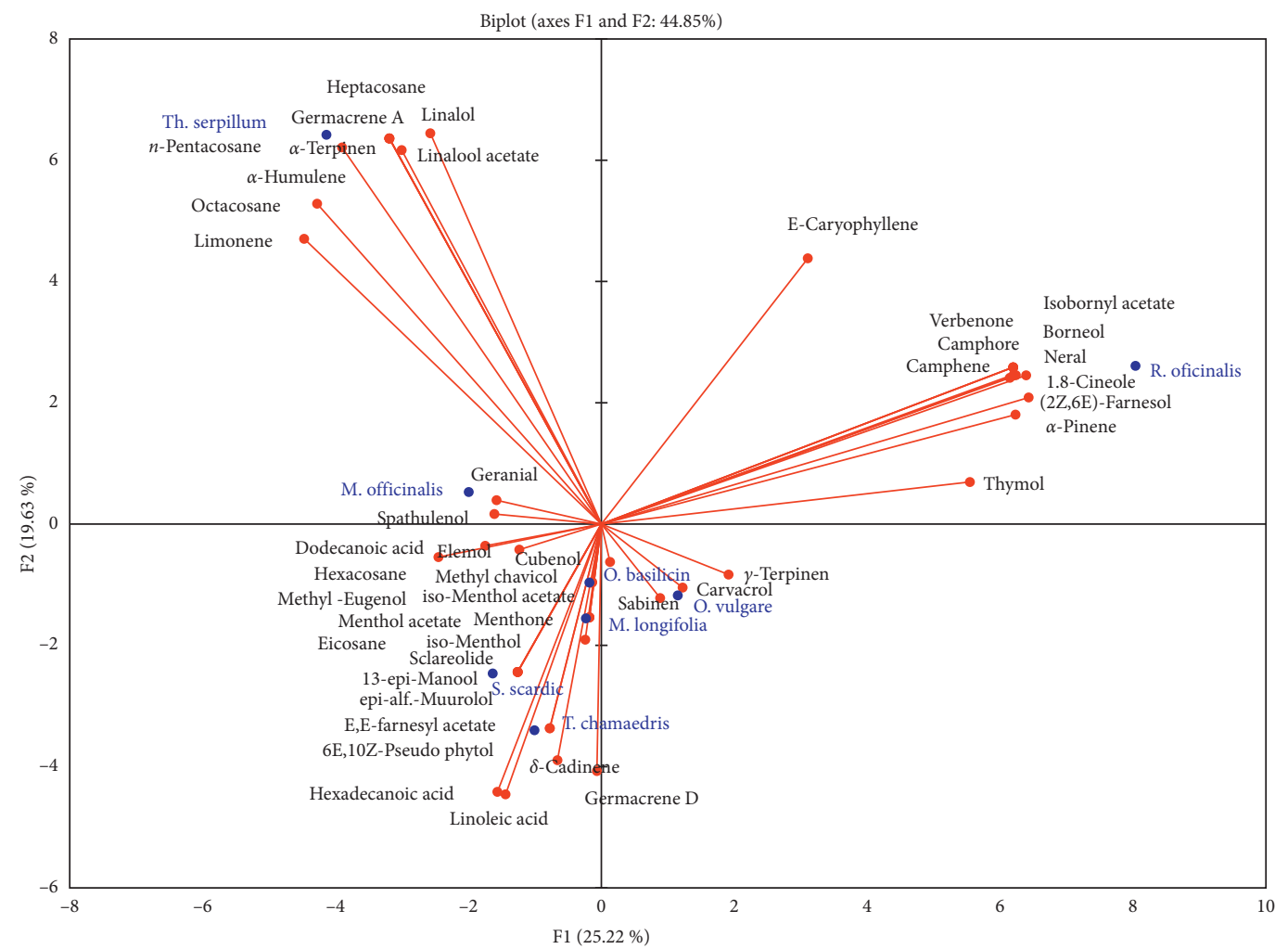

Figure 1: Diagram generated from the Principal Component Analysis of volatile compounds found in 8 plant species of the Lamiaceae family traditionally used as teas.

(13.71\%), borneol (4.41\%), isobornyl acetate (3.74\%), thymol (3.1\%), verbenone (3.00\%), and $\alpha$-terpineol (2.67\%), whereas the principal monoterpenes were $\alpha$-pinene $(10.83 \%)$, camphene $(3.28 \%)$, myrcene $(2.54 \%)$, and p-cymene $(2.58 \%)$. The percentage of sesquiterpene, E-caryophyllene, was $11.8 \%$, while the peak areas of oxygenated sesquiterpenes khusinol and 7 -epi- $\alpha$-eudesmol were $2.37 \%$ and $2.29 \%$, respectively. These results are in line with the published data on rosemary essential oil composition. Environmental, seasonal, and population-based variations in the chemical composition of rosemary essential oils have also been reported [36-39].

3.2.6. Sideritis scardica Griseb., Lamiaceae. Sixty-four constituents were detected in the essential oils obtained from aerial parts of ironwort, mountain tea, Sideritis scardica. Fatty acids and hydrocarbons were the principal components (22.25\% and $20.72 \%$, respectively). Respective peak areas of oxygenated sesquiterpenes and sesquiterpenes were $14.74 \%$ and $12.92 \%$. The less abundant constituents were oxygenated diterpenes (11.5\%), diterpenes $(4.31 \%)$, and monoterpenes $(4.33 \%)$. The most prominent compounds were fatty acids, hexadecanoic acid (12.68\%) and linoleic acid (3.99\%); hydrocarbons, eicosane $(10.89 \%)$, hexacosane (4.54\%), and $n$-tricosane $(2.31 \%)$; the oxygenated diterpene, 13-epi-manool (7.72\%); oxygenated sesquiterpenes, sclareolide (5.52\%) and caryophyllene oxide (2.09\%); sesquiterpenes, E-caryophyllene (3.9\%) and germacrene $D$ (2.54\%); the diterpene, isophyllocladene (2.33\%); and monoterpene, $\beta$-pinene $(2.35 \%)$. With regard to the composition of $S$. scardica essential oil, notable variability in its constituents has been previously reported. In samples originated from Sharri mountain (Ljuboten), essential oils were characterized by the presence of monoterpenes and sesquiterpenes $(30.01 \%$ and $25.54 \%$, respectively), and fatty 
acids and their esters and diterpenes $(16.72-71.07 \%$ for fatty acids and their esters, and from 23.30 to $72.76 \%$, for diterpenes) [40]. In Macedonian samples, the most prominent constituent was alpha-cadinol (20\%), whereas $\alpha$-pinene (4.4-25.1\%) and $\beta$-pinene $(2.8-18.0 \%)$ were predominant in the oil of Bulgarian samples. Greater levels of 1-octen-3-ol, phenylacetaldehyde, $\beta$-bisabolene, benzyl benzoate, and $\mathrm{m}$-camphorene have also been noted [18].

3.2.7. Teucrium chamaedrys L., Lamiaceae. Fifty compounds were identified in the essential oils obtained from the aerial parts of wall germander, Teucrium chamaedrys. Sesquiterpenes, hydrocarbons, and their oxygenated derivatives ( $49.3 \%$ and $11.3 \%$, respectively), followed by fatty acids and their derivatives $(23.9 \%)$, were the principal components of the essential oils. Monoterpenes and oxygenated monoterpenes made up $2.04 \%$ and $2.71 \%$ of the content, respectively, whereas the respective percentages of hydrocarbons and oxygenated diterpenes were $4.92 \%$ and $3.97 \%$. The principal constituents were sesquiterpenes, germacrene $D(24.1 \%)$; E-caryophyllene (3.96\%); $\beta$-bourbonene (2.47\%); iso-longifolene $(2.2 \%)$; oxygenated sesquiterpene, caryophyllene oxide (2.09\%); fatty acids, hexadecanoic acid (12.09\%) and linoleic acid (6.03\%); the oxygenated diterpene, pseudophytol (3.25\%); the hydrocarbon, $n$-docosane (2, 94\%); and unsaturated fatty alcohol, 1-octen-3-ol (2.92\%). These results are in accordance with other reports in the literature. The main constituents of $T$. chamaedrys oils, $\beta$-caryophyllene (26.9\%) and germacrene $D(22.8 \%)$, have been reported by Kovacevic et al. [41] and the predominance of sesquiterpene hydrocarbons was observed in samples originating from Croatia [42].

3.2.8. Thymus serpyllum L., Lamiaceae. Twenty-seven compounds were identified in the essential oils obtained from the distillation of aerial parts of wild thyme Thymus serpyllum. Oxygenated monoterpenes (44.81\%) were the principal components, followed by sesquiterpenes (22.78\%) and monoterpenes (14.17\%). Hydrocarbons were present at $13.53 \%$, whereas oxygenated sesquiterpenes and oxygenated diterpenes were present in smaller amounts $(2.38 \%$ and $1.9 \%$, respectively). The principal compounds were oxygenated monoterpenes, linalool (16.90\%), linalool acetate $(22.35 \%)$, and geranyl acetate $(2.19 \%)$; sesquiterpenes, E-caryophyllene $(8.43 \%), \alpha$-humulene $(8.87 \%)$, and germacrene A (3.53\%); and monoterpenes, $\alpha$-terpinene (7.11\%), limonene (3.10\%), and E- $\beta$-ocimene $(2.20 \%)$. Respective peak areas of hydrocarbon compounds, $n$ pentacosane, hexacosane, heptacosane, and octacosane, were $4.30 \%, 1.30 \%, 4.16 \%$, and $2.94 \%$. In T. serpyllum samples originating from Croatia and Bosnia and Herzegovina, monoterpenes were more abundant than oxygenated monoterpenes [43]. In Greece, GC-MS analysis of commercial samples revealed thymol as major component $(38.50 \%)$, followed by $p$-cymene $(8.9 \%), \gamma$-terpinene (7.2\%), bornyl acetate (7\%), borneol (6\%), and carvacrol (4.70\%) [44]. On the other hand, in samples collected from two locations in Serbia, the principal components from the first locality (Mt. Kopaonik) were trans-caryophyllene (27.7\%), $\gamma$-muurolene (10.5\%), and $\alpha$-humulene $(7.5 \%)$, whereas in the second locality (Mt. Pasjaca) the principal components were trans-nerolidol (24.2\%), germacrene $D$ $(16.0 \%)$, thymol (7.3\%), $\delta$-cadinene (3.7\%), and $\beta$-bisabolene $(3.3 \%)$ [45].

3.3. Frequency of the Species Used as Tea. Some of the plant species still have an important use as herbs in the cultures of the Sharri region.

Thus, the Origanum vulgare and Thymus serpyllum still are frequently used in regions, while Sideritis scardica is frequently used in Macedonia, as it is present in a larger population, while in Kosovo side of Sharri it is rarely used, as it grows in only a few small populations and this is an endangered species. Melissa officinalis, Ocimum basilicum, and Mentha longifolia are occasionally used to prepare tea. On the other hand, Teucrium chamaedrys and Rosmarinus officinalis are rarely used nowadays.

\section{Conclusions}

Over centuries, a considerable number of plant species in Sharri region have been used as traditional medicines, foods, and teas. In this study, eight plant species belonging to the Lamiaceae family were identified to be used as recreational tea based on review of the ethnobotanical literature. Chemical screening of the volatile constituents carried out with GC-MS and GC-FID revealed that most of these species have quite different chemical compositions (qualitatively and quantitatively) which contribute to the specific flavor and fragrance of these teas.

Further research is needed to address the preferences of the consumers on the tastes, fragrances, and colors of these recreational teas. Furthermore, research on the pharmacological, nutritional, and phytochemical properties of plants used for making tea is needed to ensure the safety and appropriateness of their use, especially for those consumed on a daily basis.

The wild plant species used for the preparation of tea represent an important national resource and therefore they need to be preserved and used in a sustainable way. The promotion of the traditional values of this group of plant species, besides their scientific importance, also represents their socioeconomic importance, since their promotion ecotourism, rural tourism, and other economic activities can be stimulated. This baseline data can be used for projects intended to foster rural development programs focusing on sustainable valorization of local herbal and wild food resources.

\section{Abbreviations}

GC-FID: Gas chromatography-flame ionization detection

GC-MS: Gas chromatography-mass spectrometry

HCA: Hierarchical cluster analysis

PCA: Principal Component Analysis. 


\section{Data Availability}

No data were used to support this study.

\section{Disclosure}

The content of this publication is the sole responsibility of the authors and does not necessarily reflect the official views of the European Union.

\section{Conflicts of Interest}

The authors declare that there are no conflicts of interest regarding the publication of this article.

\section{Authors' Contributions}

Avni Hajdari designed and supervised the experiments, conducted the botanical identification of the plant, analyzed and interpreted data, and cowrote the paper. Behxhet Mustafa designed the experiments, conducted the botanical identification of the plant, and cowrote the paper. Lirie Hyseni and Ani Bajrami collected the plant material and helped in data analysis. Genista Mustafa collected the plant material and helped in data analysis. Cassandra Leah Quave analyzed and interpreted data and revised the paper. Dashnor Nebija cowrote the paper and made a critical revision. All authors read and approved the final paper.

\section{Acknowledgments}

Part of this work was supported by the European Union under grant agreement (Grant no. 2014/355-445 IPA CBC Programme Macedonia-Kosovo 2014-2020).

\section{References}

[1] D. Ćukić, Turistička Valorizacija Prirodnih, Etnografskih I Drugih Kulturnih Potencijala Shar-Planine: Posebna Izdanja, Knjiga 55, Srpsko Geografsko Društvo, Beograd, Serbia, 1983.

[2] B. Mustafa, A. Hajdari, A. Pieroni, B. Pulaj, X. Koro, and C. L. Quave, "A cross-cultural comparison of folk plant uses among Albanians, Bosniaks, Gorani and Turks living in south Kosovo," Journal of Ethnobiology and Ethnomedicine, vol. 11, no. 1, pp. 1-26, 2015.

[3] V. Stevanović and M. M. Janković, "Pregled nekih značajnih endemičnih i reliktnih vrsta visoko planinske flore kosovskog dela Sharplanine," Priroda Kosova, vol. 1, pp. 55-82, 1984.

[4] B. Rexhepi, B. Mustafa, A. Hajdari, J. Rushidi-Rexhepi, A. Pieroni, and C. L. Quave, "Traditional medicinal plant knowledge among Albanians, Macedonians and Gorani in the Sharri Mountains (Republic of Macedonia)," Genetic Resources and Crop Evolution, vol. 60, no. 7, pp. 2055-2080, 2013.

[5] A. Pieroni, A. Nedelcheva, A. Hajdari et al., "Folk knowledge on food plants and "domestic" medicines in the mountain villages of Peshkopia, Eastern Albania," Journal of Mountain Science, vol. 11, no. 1, pp. 180-193, 2014.

[6] A. Pieroni, K. Cianfaglione, A. Nedelcheva, A. Hajdari, B. Mustafa, and C. L. Quave, "Resilience at the border: traditional botanical knowledge among Macedonians and
Albanians living in Gollobordo, Eastern Albania," Journal of Ethnobiology and Ethnomedicine, vol. 10, no. 1, p. 31, 2014.

[7] A. Pieroni, R. Sõukand, C. L. Quave, A. Hajdari, and B. Mustafa, "Traditional food uses of wild plants among the Gorani of South Kosovo," Appetite, vol. 108, pp. 83-92, 2017.

[8] Y. Dogan, A. Nedelcheva, Ł. Łuczaj et al., "Of the importance of a leaf: the ethnobotany of sarma in Turkey and the Balkans," Journal of Ethnobiology and Ethnomedicine, vol. 11, no. 1, p. 26, 2015.

[9] R. L. Sõukand, C. L. Quave, A. Pieroni et al., "Plants used for making recreational tea in Europe: a review based on specific research sites," Journal of Ethnobiology and Ethnomedicine, vol. 9, no. 1, p. 58, 2013.

[10] R. Sõukand, A. Pieroni, M. Biró et al., "An ethnobotanical perspective on traditional fermented plant foods and beverages in Eastern Europe," Journal of Ethnopharmacology, vol. 170, pp. 284-296, 2015.

[11] B. Mustafa, A. Hajdari, F. Krasniqi et al., "Medical ethnobotany of the Albanian alps in Kosovo," Journal of Ethnobiology and Ethnomedicine, vol. 8, no. 1, p. 6, 2012.

[12] A. Hajdari, A. Pieroni, M. Jhaveri, B. Mustafa, and C. L Quave, "Ethnomedical knowledge among slavic speaking people in South Kosovo," Ethnobiology and Conservation, vol. 7, p. 6, 2018.

[13] A. Hajdari, B. Mustafa, A. Kaçiku et al., "Chemical Composition of the essential oil, total fenolics, total flavonoids and antioxidant activity of methanolic extracts of Satureja Montana L," Records of Natural Products, vol. 10, no. 6, pp. 750-760, 2016.

[14] B. Pulaj, B. Mustafa, K. Nelson, C. L. Quave, and A. Hajdari, "Chemical composition and in vitro antibacterial activity of Pistacia terebinthus essential oils derived from wild populations in Kosovo," BMC Complementary and Alternative Medicine, vol. 16, no. 1, p. 147, 2016.

[15] A. Hajdari, B. Mustafa, D. Nebija, E. Miftari, C. L. Quave, and J. Novak, "Chemical composition of Juniperus communis L. cone essential oil and its variability among wild populations in Kosovo," Chemistry and Biodiversity, vol. 12, no. 11, pp. 1706-1717, 2015.

[16] A. Hajdari, B. Mustafa, V. Gashi, D. Nebija, A. Ibraliu, and J. Novak, "Chemical composition of the essential oils of ripe berries of Juniperus oxycedrus L., growing wild in Kosovo," Biochemical Systematics and Ecology, vol. 57, no. 7, pp. 90-94, 2014.

[17] M. Hatipi, V. Papajani, S. Cavar, and R. Koliqi, "Analysis of volatile compounds of Origanum vulgare L. growing wild in Kosovo," Journal of Essential Oil Bearing Plants, vol. 17, no. 1, pp. 148-157, 2014.

[18] E. Kostadinova, D. Nikolova, K. Alipieva, M. Stefova, G. Stefkov, and L. Evstatieva, "Chemical constituents of the essential oils of Sideritis scardica Griseb and Sideritis raeseri Boiss and Heldr. From Bulgaria and Macedonia," Natural Product Research, vol. 21, no. 9, pp. 819-823, 2007.

[19] S. Albayrak, A. Aksoy, O. Sagdiç, and S. Albayrak, "Antioxidant and antimicrobial activities of different extracts of some medicinal herbs consumed as tea and spices in Turkey," Journal of Food Biochemistry, vol. 36, no. 5, pp. 547-554, 2012.

[20] T. Tutin, V. Heywood, N. Burges, D. Valentine, S. Walters, and D. Webb, Flora Europaea, University Press, Cambridge, UK, 1964.

[21] The plant list, 2013, http://www.theplantlist.org/.

[22] R. P. Adams, Identification of Essential Oil Components by Gas Chromatography/Mass Spectroscopy, Allured publishing Co, Carol Stream, IL, USA, 2009. 
[23] H. Demir and S. Kalayc1, "Chemical composition and antimicrobial activity of essential oils of Ocimum basilicum var. album (L.) Benth, Lavandula angustifolia subsp. Angustifolia, Melissa officinalis belonging to Lamiaceae family," Journal of Food Science Education, vol. 7, no. 10, pp. 461-471, 2017.

[24] A. Basta, O. Tzakou, and M. Couladis, "Composition of the leaves essential oil of Melissa officinalis s. 1. from Greece," Flavour and Fragrance Journal, vol. 20, no. 6, pp. 642-644, 2005.

[25] N. Mimica-Dukic, B. Bozin, M. Sokovic, and N. Simin, "Antimicrobial and antioxidant activities of Melissa officinalis L. (Lamiaceae) essential oil," Journal of Agricultural and Food Chemistry, vol. 52, no. 9, pp. 2485-2489, 2004.

[26] D. Stanisavljević, S. Đorđević, M. Milenković et al., "Antimicrobial and antioxidant activity of the essential oils obtained from Mentha longifolia L. Hudson, dried by three different techniques," Records of Natural Products, vol. 8, no. 1, pp. 61-65, 2014.

[27] A. M. Džamić, M. D. Soković, M. S. Ristić et al., "Antifungal and antioxidant activity of Mentha longifolia (L.) Hudson (Lamiaceae) essential oil," Botanica Serbica, vol. 34, no. 1, pp. 57-61, 2010.

[28] H. Nikšić, E. Kovač-Bešović, E. Makarević, and K. Durić, "Chemical composition, antimicrobial and antioxidant properties of Mentha longifolia (L.) Huds. essential oil," Journal of Health Sciences, vol. 2, no. 3, pp. 192-200, 2012.

[29] J. Mastelic and I. Jerkovic, "Free and glycosidically bound volatiles of Mentha longifolia growing in Croatia," Chemistry of Natural Compounds, vol. 38, no. 6, pp. 561-564, 2002.

[30] M. M. Özcan and J. C. Chalchat, "Essential oil composition of Ocimumbasilicum L. and Ocimum minimum L. in Turkey," Czech Journal of Food Sciences, vol. 20, no. 6, pp. 223-228, 2011.

[31] O. Politeo, M. Jukic, and M. Milos, "Chemical composition and antioxidant capacity of free volatile aglycones from basil (Ocimum basilicum L.) compared with its essential oil," Food Chemistry, vol. 101, no. 1, pp. 379-385, 2007.

[32] M. Miloš, J. Mastelić, I. Jerković, and V. Katalinić, Chemical Composition and Antioxidant Activity of the Essential Oil of Oregano (Origanum Vulgare L.) Grown Wild in Croatia, Istituto Tetrahedron, Milano, Italy, 2000.

[33] I. Jerković, J. Mastelić, and M. Miloš, "The impact of both the season of collection and drying on the volatile constituents of Origanum vulgare L. ssp. hirtum grown wild in Croatia," International Journal of Food Science \& Technology, vol. 36, no. 6, pp. 649-654, 2001.

[34] M. Russo, G. C. Galletti, P. Bocchini, and A. Carnacini, "Essential oil chemical composition of wild populations of Italian oregano spice (Origanum vulgare ssp. hirtum (Link) Ietswaart): a preliminary evaluation of their use in chemotaxonomy by cluster analysis. 1. inflorescences," Journal of Agricultural and Food Chemistry, vol. 46, no. 9, pp. 3741-3746, 1998.

[35] L. P. Stanojević, J. S. Stanojević, D. J. Cvetković, and D. P. Ilić, "Antioxidant activity of oregano essential oil (Origanum vulgare L.)," Biologica Nyssana, vol. 7, no. 2, pp. 131-139, 2016.

[36] D. V. Lakušić, M. S. Ristić, V. N. Slavkovska, J. B. SinžarSekuli, and B. S. Lakušić, "Environment-related variations of the composition of the essential oils of rosemary (Rosmarinus officinalis L.) in the Balkan Penninsula," Chemistry and Biodiversity, vol. 9, no. 7, pp. 1286-1302, 2012.

[37] D. Lakusic, M. Ristić, V. Slavkovska, and B. Lakušić, "Seasonal variations in the composition of the essential oils of rosemary
(Rosmarinus officinalis, Lamiaceae)," Natural Product Communications, vol. 8, no. 1, pp. 131-134, 2013.

[38] S. Salido, J. Altarejos, M. Nogueras, A. Saánchez, and P. Luque, "Chemical composition and seasonal variations of rosemary oil from Southern Spain," Journal of Essential Oil Research, vol. 15, no. 1, pp. 10-14, 2003.

[39] J. C. Chalchat, R. P. Garry, A. Michet, B. Benjilali, and J. L. Chabart, "Essential oils of rosemary (Rosmarinus officinalis L.). The Chemical composition of oils of various origins (Morocco, Spain, France)," Journal of Essential Oil Research, vol. 5, no. 6, pp. 613-618, 1993.

[40] V. Tadić, D. Bojović, I. Arsić et al., "Chemical and antimicrobial evaluation of supercritical and conventional Sideritis scardica Griseb., Lamiaceae extracts," Molecules, vol. 17, no. 3, pp. 2683-2703, 2012.

[41] N. N. Kovacevic, B. S. Lakusic, and M. S. Ristic, "Teucrium species from Serbia and Montenegro," Journal of Essential Oil Research, vol. 13, no. 3, pp. 163-165, 2001.

[42] N. Bezić, E. Vuko, V. Dunkić, M. Ruščić, I. Blažević, and F. Burčul, "Antiphytoviral activity of sesquiterpene-Rich essential oils from four Croatian Teucrium species," Molecules, vol. 16, no. 9, pp. 8119-8129, 2011.

[43] T. Kulisic, A. Radonic, and M. Milos, "Antioxidant properties of thyme (Thymus vulgaris L.) and wild thyme (Thymus serpyllum L.) essential oils," Italian Journal of Food Science, vol. 17, no. 3, pp. 315-324, 2005.

[44] M. Nikolić, J. Glamočlija, F. R. Ferreira et al., "Chemical composition, antimicrobial, antioxidant and antitumor activity of Thymus serpyllum L., Thymus algeriensis Boiss. and Reut and Thymus vulgaris L. essential oils," Industrial Crops and Products, vol. 52, pp. 183-190, 2014.

[45] S. Jaric, M. Mitrovic, and P. Pavlovic, "Review of ethnobotanical, phytochemical, and pharmacological Study of Thymus serpyllum L.," Evidence-based complementary and alternative medicine, vol. 2015, p. 10, 2015. 